\title{
Equol an isoflavonoid: potential for improved prostate health, in vitro and in vivo evidence
}

\author{
Trent D Lund ${ }^{1}$, Crystal Blake ${ }^{2}$, Lihong Bu ${ }^{3}$, Amy N Hamaker ${ }^{2}$, Edwin D Lephart ${ }^{2 *}$
}

\begin{abstract}
Background: To determine: in vitro binding affinity of equol for 5alpha-dihydrotestosterone (5alpha-DHT), in vitro effects of equol treatment in human prostate cancer (LNCap) cells, and in vivo effects of equol on rat prostate weight and circulating levels of sex steroid hormones.

Methods: First, in vitro equol binding affinity for 5alpha-DHT was determined using 14C5alpha-DHT combined with cold 5alpha-DHT (3.0 nM in all samples). These steroids were incubated with increasing concentrations of equol (02,000 nM) and analyzed by Sephadex LH-20 column chromatography. 14C5alpha-DHT peak/profiles were determined by scintillation counting of column fractions. Using the $14 \mathrm{C} 5 \mathrm{alpha-DHT}$ peak ( $\mathrm{nM}$ equol) as a reference standard, a binding curve was generated by quantifying shifts in the 14C5alpha-DHT peaks as equol concentrations increased. Second, equol's in vitro effects on LNCap cells were determined by culturing cells (48 hours) in the presence of increasing concentrations of dimethyl sulfoxide (DMSO) (vehicle-control), 5alpha-DHT, equol or 5alpha-DHT+equol. Following culture, prostate specific antigen (PSA) levels were quantified via ELISA. Finally, the in vivo effects of equol were tested in sixteen male Long-Evans rats fed a low isoflavone diet. From 190215 days, animals received $0.1 \mathrm{cc}$ s.c. injections of either DMSO-control vehicle $(\mathrm{n}=8)$ or $1.0 \mathrm{mg} / \mathrm{kg}$ (body weight) of equol (in DMSO) $(n=8)$. At 215 days, body and prostate weights were recorded, trunk blood was collected and serum assayed for luteinizing hormone $(\mathrm{LH})$, 5alpha-DHT, testosterone and 17beta-estradiol levels.

Results: Maximum and half maximal equol binding to 5alpha-DHT occurred at approximately $100 \mathrm{nM}$ and $4.8 \mathrm{nM}$ respectively. LNCap cells cultured in the presence of 5alpha-DHT significantly increased PSA levels. However, in the presence of 5alpha-DHT+equol, equol blocked the significant increases in PSA levels from LNCap cells. In vivo equol treatment significantly decreased rat prostate weights and serum 5alpha-DHT levels but did not alter LH, testosterone, and estradiol levels.

Conclusions: Equol administration appears to have potential beneficial effects for prostate health and other 5alpha-DHT mediated disorders. Equol administration: reduces PSA levels from LNCap cells under 5alpha-DHT stimulation, decreases rat prostate size, decreases serum 5alpha-DHT levels and androgen hormone action, while not altering other circulating sex steroids or LH levels.
\end{abstract}

\section{Background}

Polyphenols are a group of chemical substances found in plants that include berries, grapes, walnuts, peanuts, pomegranates, and other fruits and vegetables [1]. Many of these polyphenol preparations are available as dietary supplements [2]. The largest and best studied polyphenols are the dietary estrogen-like molecules or phytoestrogens [1]. Of the three main classifications of

\footnotetext{
* Correspondence: edwin_lephart@byu.edu

${ }^{2}$ The Department of Physiology and Developmental Biology and the Neuroscience Center, Brigham Young University, Provo, Utah 84602, USA Full list of author information is available at the end of the article
}

phytoestrogens: 1) isoflavones (derived principally from soybeans), 2) lignans (found in flaxseed in large quantities), and 3) coumestans (derived from sprouting plants like alfalfa), human consumption of isoflavones has the largest impact due to its availability and variety in food products. Isoflavones have been implicated as potential treatments for many disorders including cardiovascular disease, osteoporosis, age-related diseases, and hormone-dependent cancers $[3,4]$.

However, these isoflavone molecules do not exist at high levels in their biologically active form in natural food products, but rather are at high abundance in a 
precursor form [3-5]. For example, daidzin, the precursor of daidzein, is the glycosidic form that contains a carbohydrate portion of the molecule. Daidzin is metabolized in the gastrointestinal tract by intestinal bacteria, which hydrolyze the carbohydrate moiety, to the biologically active isoflavone, daidzein $[4,5]$. Daidzein is then further metabolized in the intestine to equol at relatively low or high levels dependent upon several biological, dietary and presumably environmental factors $[4,5]$. Although, recent evidence suggests that equol is found naturally in white cabbage [6].

Equol has recently caught the interest of many researchers due to its rich antioxidant activity and implications in cancer research $[4,5]$. The chemical structure of equol contains a stereocenter at carbon number 3 which gives it two possible enantiomers and it has since been proven that the production of equol by microflora in mammals or other animals is selective for the S - enantiomer only [5]. $\mathrm{S}$-equol has unique chemical properties compared to its $\mathrm{R}$ - enantiomer. S-equol has been shown to have a modest affinity for binding to and mimicking estrogen's effects on estrogen beta receptors (ER $\beta)$ due to its similar structure to natural estrogens $[5,7]$. However, S-equol shows little affinity for estrogen alpha receptors (ER $\alpha)$. Furthermore, equol (i.e., the R- and/or S-isomer) can act as an antiandrogen [7]. Equol's anti-androgen activity is unique as equol does not bind the androgen receptor (AR) but specifically binds $5 \alpha$-dihydrotestosterone ( $5 \alpha-\mathrm{DHT})$ with high affinity, and thereby prevents DHT from binding the AR [7], see Figure 1. This finding is reconfirmed and extended here. Additionally, equol's mechanism of action, namely, its ability to specifically bind $5 \alpha$-DHT and prevent $5 \alpha$ DHT's biological actions in physiological processes, was studied.

For example, it is known that prostate cancer cells are supported in their growth by androgen stimulation and the androgen-regulated expression of the prostate specific antigen (PSA) is a biological marker of such stimulation [8]. Logically, any treatment that could decrease PSA levels in prostate cancer cells, or antagonize specific androgen hormone action, would have great potential in

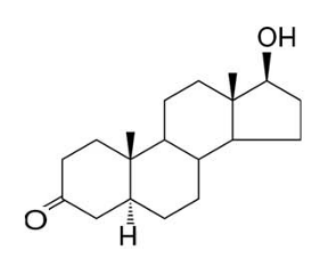

5a-Dihydrotestosterone (5a-DHT)

Figure 1 Biochemical structures of dihydrotestosterone and equol. addressing prostate disorders, such as benign prostatic hyperplasia $(\mathrm{BPH})$ or prostate cancer. With this in mind, we sought, in the following experiments, to determine equol's effect on $5 \alpha$-DHT levels in cultured human prostate cancer (LNCap) cells. We also examined equol's effect on both prostate weight and circulating hormone levels in vivo using Long-Evans rats. In brief, the present results demonstrate that equol: a) (R-and/or S-isomeric mixtures) has high binding affinity for $5 \alpha$-DHT making it a potent selective androgen modulator (SAM), b) blocks the stimulatory androgen action of $5 \alpha$-DHT in increasing prostate specific antigen (PSA) levels in human cancer (LNCap) cell cultures and, c) significantly decreases serum $5 \alpha$-DHT and subsequently prostate weight without altering, testosterone, $17 \beta$-estradiol or LH levels. Applications for equol to improve prostate disorders and other androgen-mediated conditions is also discussed.

\section{Methods}

\section{Experiment 1. In vitro binding of Equol (Isomer Ratio) to $5 \alpha$-DHT \\ Samples}

In a $20 \mathrm{ml}$ amber glass vial approximately 4,000 to 5,000 dpm of ${ }^{14} \mathrm{C} 5 \alpha$ - Dihydrotestosterone (DHT; Dupont/ NEN, Boston, MA, USA) was added. Additionally, 3.0 $\mathrm{nM}$ (or approximately $865 \mathrm{pg} / \mathrm{ml}$ ) of cold $5 \alpha-\mathrm{DHT}$ (Sigma/Aldrich Chemical Co., St. Louis, MO, USA) was added (in all experiments) and where appropriate varying concentrations of equol $(70 \% \mathrm{R}$-equol and $30 \% \mathrm{~S}$ equol mixture; from 0 to 2,000 $\mathrm{nM}$; obtained from $\mathrm{LC}$ Labs., Woburn, MA,USA or Robert Handa's Laboratory, Colorado State University, USA, R-equol or S-equol isomers only) from ethanol stock solutions. This mixture was vortexed for 30 seconds at room temperature and then dried down. Subsequently $1 \mathrm{ml}$ of TEGMD (10 $\mathrm{mM}$ Tris CL, $1.5 \mathrm{mM}$ EDTA, $10 \%$ glycerol, $25 \mathrm{mM}$ molybdate and $1 \mathrm{mM}$ dithrothreitol) buffer was added, capped, and mixed by inverting the vial 3 -times. This mixture was incubated at room temperature for 20-24 hours before being placed on a Sephadex column [7].

\section{Columns}

Sephadex LH-20 (25-100 $\mu$ m particle diameter) from Sigma/Aldrich Chemical Co. (St. Louis, MO, USA), was used to prepare $1.3 \mathrm{~cm} \times 25 \mathrm{~cm}$ columns, as described by Lund et al [7]. Sephadex (0.25 grams) was mixed with $1.5 \mathrm{ml}$ of TEGMD buffer. The serological pipette was plugged with a glass bead and $1 \mathrm{ml}$ of Sephadex was loaded onto the column with TEGMD buffer and equilibrated. Flow rates under gravity were approximately $0.5 \mathrm{ml} / \mathrm{min}$ and $0.5 \mathrm{ml}$ fractions were collected in plastic scintillation vials.

\section{Quantification}

Five ml of Ultima Gold scintillation fluid (Packard Instr. Co., Meriden, CT, USA) was added to each vial, mixed 
thoroughly and counted for 5 min. in a Beckmann LS 6500 scintillation counter. The peak ${ }^{14} \mathrm{C} 5 \alpha$-DHT fraction and profile using $0 \mathrm{nM}$ of equol was used as reference. The shift (advancement) in peak/profile in subsequent experiments using increasing concentrations of equol $(70 \% \mathrm{R}$-isomer and 30\% $\mathrm{S}$-isomer in this experiment) was calculated based upon this reference (as arbitrary binding units as a percentage of the original reference, $\mathrm{n}=6$ for $0 \mathrm{nM}$ of equol). Note: data not shown, 2,000 $\mathrm{nM}$ of equol was tested in this experiment which yielded $100.0 \% \pm 0.3$ (s.e.m.) binding, $\mathrm{n}=3$. Finally, over thirty steroid hormones were tested (see Table 1) (in preliminary studies to determine the selectivity and specificity of equol for binding $5 \alpha-\mathrm{DHT})$. The steroids were purchased from Steraloids, Inc., Newport, RI, USA or Sigma/Aldrich Chem. Co., St. Louis, MO, USA.
Experiment 2. In vitro blockade of $5 \alpha$-DHT stimulated Prostate Specific Antigen (PSA) levels in LNCap cells by equol: Human Prostate Cancer Cell Cultures

Human prostate cancer cell line was obtained from American Type Culture Collection (ATCC; Manassas, VA, USA; ATCC \# CRL-1740, LNCap-FGC) and cultured in a $37^{\circ} \mathrm{C}$, humidified incubator with $5 \% \mathrm{CO}_{2}$, in RPMI Medium (Sigma/Aldrich Cat. \# R-8758) with 5\% fetal bovine serum (Hyclone/Thermo Sci., Waltham, MA, USA, Cat. \# SH30088.03, Lot number APC20780) and $5 \mathrm{mM}$ Hepes (Sigma/Aldrich Cat. H-0887), 1× antibiotic/antimycotic (Sigma/Aldrich Cat. \# A5955). Cells were expanded in T-150 flasks for three passages until cryopreservation and storage in liquid nitrogen in RPMI medium with 10\% FBS and 10\% DMSO as cryopreservative. A cryovial was then thawed in a $37^{\circ} \mathrm{C}$ water bath, expanded again one or two passages, and then plated at

Table 1 Steroid compounds tested in Equol Binding Assays

\begin{tabular}{|c|c|}
\hline Chemical Name & Trivial Name \\
\hline 4-ANDROSTEN-17 $\beta-O L-3-O N E$ & TESTOSTERONE \\
\hline 5-ANDROSTEN-3 $\beta-O L-17-O N E$ & DHEA \\
\hline $5 \alpha$-ANDROSTAN-3 $\alpha, 17 \beta$-DIOL & 17ß-DIHYDROANDROSTERONE \\
\hline $5 \alpha$-ANDROSTAN-3 $\beta, 17 \alpha$-DIOL & NA \\
\hline 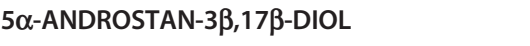 & NA \\
\hline 5 $\alpha$-ANDROSTAN-3,17-DIONE & ANDROSTANEDIONE \\
\hline $5 \alpha-A N D R O S T A N-17 \beta-O L-3-O N E$ & $5 \alpha-\mathrm{DHT}$ \\
\hline 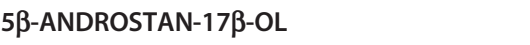 & NA \\
\hline 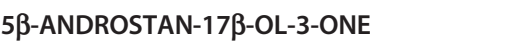 & $5 \beta-\mathrm{DHT}$ \\
\hline 4-ANDROSTEN-3,17-DIONE & ANDROSTENEDIONE \\
\hline 1,3,5(10)-ESTRATRIEN-3,17 $\alpha$-DIOL & EPIESTRADIOL \\
\hline 1,3,5(10)-ESTRATRIEN-3,17ß-DIOL & ESTRADIOL (E2) \\
\hline 1,3,5(10)-ESTRATRIEN-3,16 $\alpha, 17 \beta$-TRIOL & ESTRIOL (E3) \\
\hline 1,3,5(10)-ESTRATRIEN-3-OL-17-ONE & ESTRONE (E1) \\
\hline $5 \alpha$-ESTRAN-3,17-DIONE & $5 \alpha$-DIHYDROANDROSTENEDIONE \\
\hline 5-PREGNEN-3ß-OL-20-ONE & PREGNENOLONE \\
\hline 4-PREGENEN-3,20-DIONE & PROGESTERONE (P4) \\
\hline $5 \alpha$-PREGNAN-3 $\alpha-O L-20-O N E$ & ALLOPREGNANOLONE \\
\hline 5 $\alpha$-PREGNAN-11 $\beta, 21$-DIOL-3, 20-DIONE & ALLODIHYDROCOSTERONE \\
\hline 5 $\alpha$-PREGNAN-3 $\alpha, 11 \beta, 21$-TRIOL-20-ONE & ALLOTETRAHYDROCORTICOSTERONE \\
\hline 5 $\alpha$-PREGNAN-3 $\beta, 21 \beta, 21-T R I O L-20-O N E$ & EPIALLOTETRAHYDROCORTICOSTERONE \\
\hline 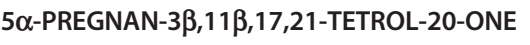 & $3 \beta, 5 \alpha$-TETRAHYDROCORTISOL \\
\hline 5 $\alpha$-PREGNAN-11 $\beta, 17,21-T R I O L-3,20-D I O N E$ & ALLODIHYDROCORTISOL \\
\hline 5 $\alpha$-PREGNAN-17,21-DIOL-3,11,20-TRIONE & ALLODIHYDROCORTISONE \\
\hline $5 \alpha$-PREGNAN-3 $\beta$-OL-20-ONE & $5 \alpha$-DIHYDROPREGNANOLONE \\
\hline 5 $\alpha$-PREGNAN-3, 20-DIONE & $5 \alpha$-DIHYDROPROGESTERONE ( $5 \alpha$-DHP) \\
\hline $5 \beta$-PREGNAN-3 $\alpha-O L-20-O N E$ & $3 \alpha-$-HYDROXY-5 $\beta$ TETRAHYDROPROGESTONE \\
\hline $5 \beta$-PREGNAN-11 $\beta, 21$-DIOL-3,20-DIONE & $5 \beta$-DIHYDROCORTICOSTERONE \\
\hline $5 \beta$-PREGNAN-3 $\alpha, 11 \beta, 21-$ TRIOL-20-ONE & TETRAHYDROCORTICOSTERONE \\
\hline $5 \beta$-PREGNAN-3 $\alpha, 11 \beta, 17,21$-TETROL-20-ONE & TETRAHYDROHYDROCORTISOL \\
\hline $5 \beta$-PREGNAN-11 $\beta, 17,21$-TRIOL-3,20-DIONE & 5ß-DIHYDROCORTISOL \\
\hline $5 \beta$-PREGNAN-17,21-DIOL-3,11,20-TRIONE & $5 \beta$-DIHYDROCORTISONE \\
\hline 5ß-PREGNAN-3,20-DIONE & $5 \beta$-DIHYDROPROGESTERONE ( $5 \beta$-DHP) \\
\hline
\end{tabular}


10,000 cells per 96 well in $0.2 \mathrm{ml}$ medium in 96 well plates in RPMI 5\% FBS medium. After approximately 48 hours, the medium was changed to phenol red-free DMEM/F12 (Gibco/Invitrogen, Carlsbad, CA, USA, Cat. \#21041-025) with $2 \%$ FBS and $1 \times$ antibiotic/antimycotic and test materials ( $5 \alpha-$ DHT, equol or $5 \alpha$-DHT plus equol; $\mathrm{n}=6$ per treatment) and DMSO/vehicle controls were added at the appropriate concentration (either, 0.1 $\mathrm{nM}, 1.0 \mathrm{nM}$ or $10 \mathrm{nM}$ of $5 \alpha-$ DHT or $100 \mathrm{nM}, 10 \mathrm{nM}$ or $1.0 \mathrm{nM}$ of equol) from $10 \times$ stocks for specific experiments. [The change to phenol red-free medium was to eliminate any potential estrogenic influence]. Cells were cultured for approximately 48 hours in the presence of the test materials and controls prior to removal of medium supernatants for prostate specific antigen (PSA) ELISA quantification.

\section{MTT Assay}

Cytotoxicity was determined by spectrophotometric detection of reduced 3-(4,5-dimethylthiazol-2-yl)-2,5diphenyltetrazolium bromide (MTT, Sigma/Aldrich Cat \# 5655) at $550 \mathrm{~nm}$ using a Molecular Devices Vmax 96 well plate reader and SoftMax software $(n=6$ per treatments or controls). Metabolic activity can be used as a measure of cytotoxicity, in that the intensity of the reduced form of MTT by live cells is directly proportional to cellular viability, and inversely proportional to cytotoxicity.

\section{Cellular DNA Assay}

Cellular DNA was determined using a CyQuant Cell Proliferation Kit (Molecular Probes/Invitrogen, Carlsbad, CA, USA, Cat \# C7026) according to the manufacture's instructions to quantify cellular proliferation.

\section{PSA ELISA}

Tissue culture supernatants were diluted 10-fold in PBS and stored at $-20^{\circ} \mathrm{C}$, then thawed at room temperature prior to assay. A commercial ELISA kit for free PSA (Bio-Quant, San Diego, CA, USA, Cat. \# BQ 067T) was utilized according to the manufacturer's instructions, and data was determined using a Molecular Devices Vmax 96 well plate reader and SoftMax software.

\section{Experiment 3. In vivo blockade of the stimulatory effects of $5 \alpha-\mathrm{DHT}$ by equol}

This is an example of equol preventing the stimulatory effects of $5 \alpha$-DHT in vivo. Rats were injected with $1 \mathrm{mg}$ of non-racemic equol (52\% S-isomer, $48 \% \mathrm{R}$-isomer) for 25 consecutive days, and serum $5 \alpha$-DHT levels and prostate weights were measured. Adult (50 day-old) males $(\mathrm{n}=16)$, purchased from Charles River Laboratories (CRL; Wilmington, MA, USA), were caged individually and housed in the Brigham Young University Vivarium and maintained on an 11-dark, 13-hour light schedule (lights on 0600-1900). Before purchase, the male animals were fed a diet containing approximately
$200 \mathrm{ppm}$ of isoflavones at the supplier (CRL). At 50 days of age, upon arrival, the male rats were placed on a diet containing approximately $10 \mathrm{ppm}$ of isoflavones; referred to hereafter as the low isoflavone diet (Zeigler Bros., Gardnes, PA, USA; Phytoestrogen Reduced Rodent Diet II). All animals remained on the low isoflavone diet until 216 days of age to exclude the influence of dietary isoflavones on the measured parameters. At 150 days of age the rats were divided into two groups (control or equol treatments) that were matched by age and body weight. Starting at 190 days of age the male rats received a daily subcutaneous $0.1 \mathrm{cc}$ injection at the nape of the neck of vehicle $(n=8)$ (dimethyl sulfoxide; DMSO) or equol $(\mathrm{n}=8)$ at a dose of approximately 1.0 $\mathrm{mg} / \mathrm{kg}$ for 25 consecutive days.

The body weights for each group were recorded weekly starting at 150 days of age before the treatments were initiated, with weights obtained immediately before and after the treatments were administered (there were no significant differences in body weights between the control and equol groups at the start of this experiment). At 216 days of age the animals were weighed [grams (g) $\pm 0.1 \mathrm{~g}$ ], then anesthestized with Ketamine/ acepromazine and blood was collected from the heart. Next the ventral prostate organ was dissected and weighed [milligrams $(\mathrm{mg}) \pm 0.001 \mathrm{mg}$ ]. The collected blood samples were centrifuged and serum was stored at $-20^{\circ} \mathrm{C}$ until assayed. All collection procedures were performed blind to the treatments. This animal protocol was approved by the Institutional Animal Care and Use Committee at Brigham Young University.

Serum testosterone, $5 \alpha$-DHT, and $17 \beta$-estradiol were quantified by radioimmunoassay (RIA) kits purchased from Diagnostic System Laboratories (Webster, TX, USA). Luteininzing hormone ( $\mathrm{LH}$ ) was quantified by an assay utilizing standards from the National Institutes of Health (NIH) USA pituitary hormone program. The samples were run in duplicate for each RIA, with internal control samples. In all RIAs, the control values were within normal ranges. The intra-assay coefficients of variance for the assays were: testosterone $=6.0 \%$; for $5 \alpha$-dihydrotestosterone $=8 \%, 17 \beta$-estradiol $=5 \%$ and $\mathrm{LH}=9 \%$.

\section{Reagents and supplies}

All reagents and supplies not specifically mentioned (e.g., EDTA, DMSO, glycerol, dithrothreitol, pipettes, 1.3 $\times 25 \mathrm{~cm}$ columns, etc.) were purchased from Sigma/ Aldrich Chem. Co., St. Louis, MO, USA.

\section{Statistical analyses}

Where appropriate, data were analyzed by analysis of variance statistics (ANOVA) followed by Newman-Keuls post hoc tests. Significance was $\mathrm{p}<0.05$. Curve fitting, scientific graphing, and analysis were completed using GraphPad Software (GraphPad Prism 3.0, San Diego, CA, USA). 


\section{Results}

\section{Experiment 1}

In preliminary studies, Table 1 shows 33 different steroid compounds that were tested in binding assays (outlined above) to determine equol's affinity for binding to each. While equol has modest affinity for some $5 \alpha$ reduced steroids, equol displayed the highest affinity for $5 \alpha$-dihydrotestosterone ( $5 \alpha-\mathrm{DHT})$ and had no affinity for $5 \beta$-dihydrotestosterone ( $5 \beta$-DHT) or some of the most common natural sex steroids, such as: estradiol, estrone, estriol, progesterone or testosterone. [Notably: as tested in these assays, the isoflavones: genistein and daidzein do not bind $5 \alpha-\mathrm{DHT}]$.

As shown in Figure 2, using ${ }^{14} \mathrm{C} 5 \alpha$-DHT as the tracer in the presence of $3.0 \mathrm{nM}$ (or approximately $865 \mathrm{pg} / \mathrm{ml}$ ) of cold DHT (in all samples, representing a high-normal level of circulating $5 \alpha$-DHT in men) varying concentrations of equol (70\% R-equol and 30\% S-equol mixture) from 0 to 2,000 $\mathrm{nM}$ yielded the binding curve displayed in this Figure. [The 2,000 nM dose is not graphically displayed in this Figure]. Maximum and half maximal equol binding to $5 \alpha$-DHT occurred at approximately $100 \mathrm{nM}$ and $4.8 \mathrm{nM}$, respectively. The number of samples tested at each concentration of equol examined ranged between 2 to 6 replicates (see Figure 2). [For conversion purposes, a concentration of $10.3 \mathrm{nmol} / \mathrm{L}$ of equol is approximately equivalent to $2.5 \mathrm{ng} / \mathrm{ml}$ of equol].

Notably, equol at a $70 \% \mathrm{R}$-isomer and $30 \% \mathrm{~S}$-isomer ratio was tested in this experiment. However, racemic equol or equol at a $30 \% \mathrm{R}$-isomer and $70 \% \mathrm{~S}$-isomer ratio when tested in these assays yielded similar results to that displayed in Figure 2. These data suggest that equol, regardless of the isomer ratio mixture can binding selectively $5 \alpha$-DHT in vitro.

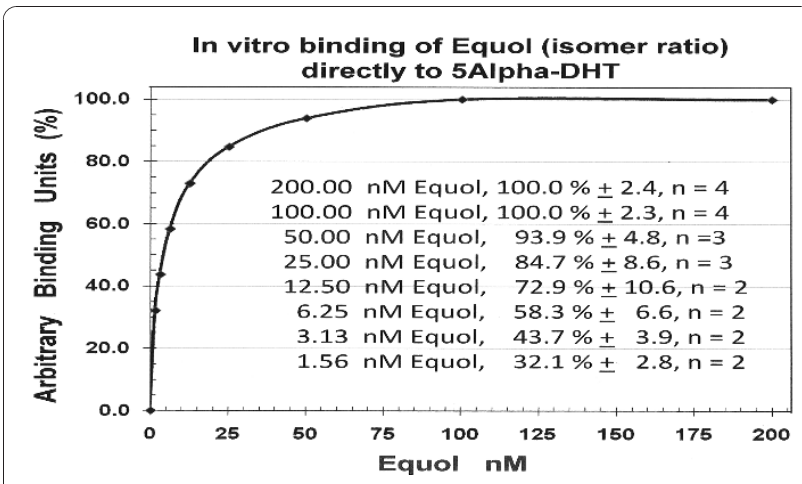

Figure 2 In vitro binding of equol (isomer ratio) to $5 \alpha-\mathrm{DHT}$ ${ }^{14} \mathrm{C} 5 \alpha$ - Dihydrotestosterone served as the tracer and $3.0 \mathrm{nM}$ (or approximately $865 \mathrm{pg} / \mathrm{ml}$ ) of cold $5 \alpha-\mathrm{DHT}$ was added (in all experiments) and where appropriate varying concentrations of equol (70\% R-equol and 30\% S-equol mixture; from 0 to 2,000 (see methods). All data expressed as the mean of the percent binding \pm SEM (see insert).

\section{Experiment 2}

This is an example of the effects of equol preventing the stimulatory effects of $5 \alpha$-DHT in LNCap prostate cancer cells in vitro from secreting prostate-specific antigen (PSA), a molecule known to be regulated by $5 \alpha-\mathrm{DHT}$, as measured by PSA ELISA (Figure 3). Treatment with $0.1,1$ or $10 \mathrm{nM}$ of $5 \alpha-\mathrm{DHT}$; 1,10 or $100 \mathrm{nM}$ of equol or a combination of $5 \alpha$-DHT plus equol (0.1 nM $5 \alpha-$ DHT and $1 \mathrm{nM}$ equol; $1 \mathrm{nM} 5 \alpha-\mathrm{DHT}$ and $10 \mathrm{nM}$ equol or $10 \mathrm{nM} 5 \alpha$-DHT and $100 \mathrm{nM}$ equol). Each obtained value represents 6 replicates + standard error of the mean (sem). Cytotoxicity, as assessed by MTT Assay, did not influence PSA production by LNCap prostate cancer cells for any of the treatments or controls (data not shown). Also, while DHT treatment has been reported to increase cellular proliferation of this cell line in vitro [9], none of the treatments significantly altered cellular proliferation as quantified by the cellular DNA assay (data not shown).

As shown in Figure 3: In the 1, 10 or 100 nM Vehicle (DMSO) treatments PSA levels did not differ from the No Treatment baseline group and controls were not significantly different from each other. Treatment with 0.1 , 1 or $10 \mathrm{nM} 5 \alpha$-DHT stimulated PSA secretion to

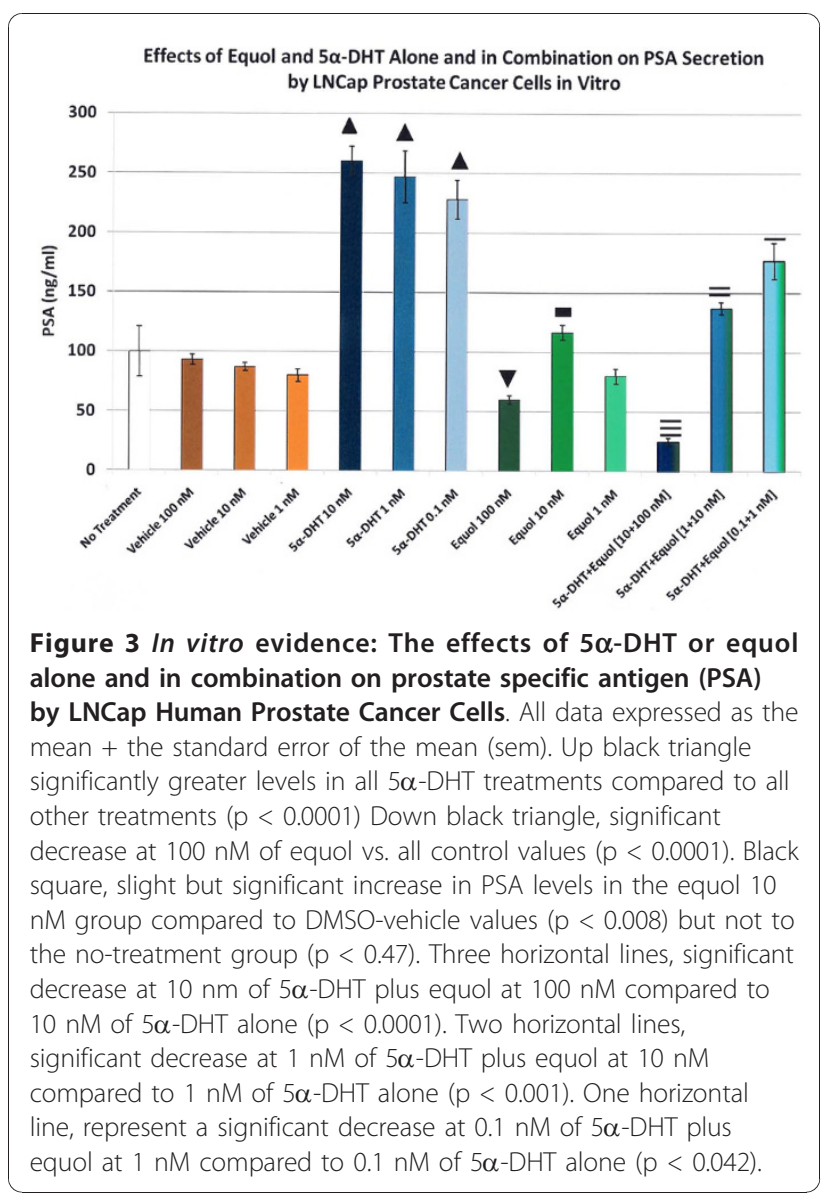


maximal levels (ranging from 228.3 to $260 \mathrm{ng} / \mathrm{ml}$ ). PSA levels from cells treated with 1,10 or $100 \mathrm{nM}$ equol were well below DHT-treated values. In fact, the 100 $\mathrm{nM}$ equol treatment alone yielded a PSA level at $60 \mathrm{ng} /$ $\mathrm{ml}$ that was significantly decreased below all vehiclecontrol values (at approximately $87 \mathrm{ng} / \mathrm{ml}$ ). The equol treatment at $10 \mathrm{nM}$ slightly but significantly increased PSA levels (to $116.7 \mathrm{ng} / \mathrm{ml}$ ) compared to all the DMSOvehicle-control values around $87 \mathrm{ng} / \mathrm{ml}$, but not to the no-treatment group at $100 \mathrm{ng} / \mathrm{ml}$ ). [This may be due to the number of replicates (6) in this experiment where standard error of the mean (sem) values were relatively small]. However, combinations of $10 \mathrm{nM} 5 \alpha$-DHT plus $100 \mathrm{nM}$ equol, as well as $1 \mathrm{nM} 5 \alpha$-DHT plus $10 \mathrm{nM}$ equol, and $0.1 \mathrm{nM} 5 \alpha-\mathrm{DHT}$ plus $1 \mathrm{nM}$ equol treatments abrogated the increase in PSA secretion, compared to the $5 \alpha$-DHT treatments alone, at the respective androgen concentrations (see Figure 3). Taken together with the in vitro binding demonstrated in Figure 2, these data from experiment 2 , suggest that equol binds the $5 \alpha$-DHT molecule and biologically inactivates it in human cancer prostate cells.

\section{Experiment 3}

To determine whether equol can bind $5 \alpha$-DHT in vivo, adult male Long-Evans rats were treated with equol for 25 consecutive days (@ $1 \mathrm{mg} / \mathrm{kg}$ via s.c. injections). Equol-injected animals displayed an approximately 50\% decrease in serum $5 \alpha$-DHT compared to (DMSO) vehicle-injected control animals (Table 2). This finding corresponds with the significant decrease in androgen hormone action which is known to regulate prostatic cell proliferation, and hence, prostate weight. Prostate weights were significantly decreased by approximately $20 \%$ in the equol-injected males compared to control rats (either alone or when prostate weights were standardized with body weights).

When LH and testosterone were quantified between the treatment groups there were no significant differences in these hormone levels (Table 2). Since LH is the gonadotrophin regulating testosterone synthesis from Leydig cells

Table 2 Serum $5 \alpha$-DHT levels, prostate weights and reproductive parameters in Equol-treated male rats

\begin{tabular}{llll}
\hline Parameter measured & Vehicle & Equol & Change \\
\hline Prostate Weight (PW), mg & $535 \pm 23$ & $429 \pm 30^{* *}$ & $20 \% \downarrow$ \\
PW/100 g Body Weight & $76 \pm 4$ & $61 \pm 5^{* *}$ & $20 \% \downarrow$ \\
Luteinizing Hormone (LH), ng/ml & $1.6 \pm 0.2$ & $1.3 \pm 0.1$ & NSC \\
Serum Testosterone, $\mathrm{ng} / \mathrm{ml}$ & $2.1 \pm 0.4$ & $2.3 \pm 0.5$ & $\mathrm{NSC}$ \\
Serum $5 \alpha-\mathrm{DHT}, \mathrm{pg} / \mathrm{ml}$ & $100 \pm 18$ & $52 \pm 5^{*}$ & $50 \% \downarrow$ \\
Serum $17 \beta$-Estradiol, $\mathrm{pg} / \mathrm{ml}$ & $3.4 \pm 0.6$ & $4.8 \pm 0.7$ & $\mathrm{NSC}$ \\
\hline
\end{tabular}

$\mathrm{n}=8$ animals per group. NSC $=$ no significant change. The data are expressed as the mean \pm standard error of the mean (sem) for each parameter.

${ }^{* *}=p<0.016^{*}=p<0.001$. in the testes, this is not a surprising result. Finally, when $17 \beta$-estradiol levels were determined there were no significant differences between the treatment groups. All hormone levels were within normal ranges of that expected for this strain, age and sex of rat. Notably, Long-Evans rats do not develop spontaneously prostate cancer but enlargement of prostatic tissue is observed with aging.

This in vivo study demonstrates that equol can contact and biologically inactive the $5 \alpha$-DHT molecule as shown by the significant decrease in $5 \alpha$-DHT levels in blood and significantly reduced prostate weights of equol-treated male rats. Finally, the in vitro and in vivo studies reported above demonstrates that equol may be effective in treating prostate disorders or other androgen-mediated diseases that are regulated by the hormone $5 \alpha$-DHT.

\section{Discussion}

The binding assays in the present study confirm and extend previous findings from our laboratories [7]. However, this protein and cell-free assay represents a system that is absent of steroid-binding proteins and other biologicals that may influence the in vivo interaction between equol and $5 \alpha$-DHT. Moreover, after testing over 30 steroid hormones with various androgenic, estrogenic or progestin chemical configurations, equol (racemic or nonracemic mixtures) specifically binds $5 \alpha$-DHT with apparent equal affinity since the bind curves obtained were very similar using different equol isomer ratios. This suggests several important issues. First, all humans have plasma levels of S-equol circulating in their bloodstream that may represent a natural modulation of the potent androgen, $5 \alpha$-DHT, regardless of whether or not they are "equol producers" $[4,5]$. Second, this circulating equol is derived from consumption of soy- or high content isoflavone-containing food products or low abundant isoflavone foods such as corn, wheat, cow's milk, etc., as a primary consumer. Finally, because grazing or other animals that produce high levels of S-equol naturally that are then consumed, such as meat products, by humans represents a source of equol as a secondary consumer. Evidence to support this last notion is shown in humans that consume high meat and fat diets display higher blood isoflavone/equol levels [10].

This denotes an interesting 'natural' modulation of $5 \alpha$-DHT in humans, since all individuals consume food products that contain the precursor daidzein molecule or equol itself (i.e., soy, corn, wheat, cow's milk or animal meat products, etc.) $[4,6,11-13]$. In fact, whether or not swine were fed a soy-containing or protein-supplemented diet the serum equol levels between the dietary treatment groups were essential the same [14]. Since the apparent half-maximal binding of equol to $5 \alpha$-DHT occurred at $4.8 \mathrm{nM}$ (or approximately $1.2 \mathrm{ng} / \mathrm{ml}$ ) the 
very low level of circulating equol may alter androgen hormone action in a manner previous unknown in normal physiological conditions. Also, the apparent half-life of R- or S-equol in humans is 5 to 6 hours [5], suggesting a viable time interval and mechanism of action. While the present data were derived from in vitro binding studies that does not represent the complex physiological environment this viewpoint will be covered below in reference to prostate health.

Further evidence presented in this study for equol binding $5 \alpha$-DHT is presented in the experiment where equol blocked the stimulatory androgen action of $5 \alpha$-DHT in increasing PSA levels in human cancer cell cultures. Although, this may be the major mechanism of action, it is known that equol (particularly S-equol) has an affinity for ER $\beta$ [5]. Previous laboratories, including ours, have shown that isoflavones binding to ER $\beta$ in the prostate can down regulate the androgen receptor (AR) and thus decrease androgen hormone action [15]. Since PSA is an androgen-regulated gene this idea may have merit $[16,17]$. In addition to equol directly binding $5 \alpha-\mathrm{DHT}$, it may alter AR expression and hence significantly decreased PSA levels in the present study. Support for this view comes from the significant decrease in PSA levels with equol treatment alone (@100 nM) in experiment 2 that displayed values even below baseline (vehicle) PSA concentrations. However, it could be argued that the fetal bovine serum provided a background androgenic stimulation and this may also account for this observation. In any event, the results of this experiment demonstrate the positive influence equol has on PSA levels and implicates potential applications of equol for prostate disorders. Finally, phase II clinical trial data examining dietary intervention with isoflavone supplementation in men with recurrent prostate cancer display a decline in PSA levels that support our present in vitro data [18].

As mentioned earlier, equol has the ability to bind ER $\beta$. This may explain how isoflavones accumulate in prostate tissue and prostatic fluid after oral supplementation [19-21] and it has been shown that binding ER $\beta$ in the prostate decreases inflammation and carcinogenesis [22]. Furthermore, this not only applies to prostate health but to other tissue-specific sites in the body where ER $\beta$ is present. For example, there is an abundance of ER $\beta$ in the brain, specifically in the frontal cortex and raphe nuclei as well as other brain regions that may be involved in mechanisms of anxiety and depression [23-25]. Preliminary data from our laboratory suggest that equol treatment in aged-rats after natural ovarian failure is effective as an anti-depressive agent at low concentrations that significantly increase serotonin levels. Additionally, the skin represents the largest organ of the body where ER $\beta$ is abundant in the epidermal and dermal regions, especially the keratinocytes and fibroblasts, respectively which may be tissue sites for beneficial alterations in androgen hormone action [26]. For instance, it is known the androgens decrease, whereas, estrogenic compounds enhance wound healing [27] that may have effective applications for topical treatments.

The results of the third experiment demonstrated that equol can significantly decrease serum $5 \alpha$-DHT along with a significant decline in prostate weight without altering, testosterone, $17 \beta$-estradiol or LH levels. There is evidence that Asian cultures have lower prostate cancer rates compared to Western cultures $[1,3,28]$. Furthermore, when data is stratified examining individuals that produce equol naturally after soy consumption suggest that lower cancer rates are due to the beneficial influence of this isoflavonoid molecule [29].

Moreover, while equol has been shown to have positive benefits in human prostate health, there is evidence that $\mathrm{R}$-, rather than the $\mathrm{S}$ - enantiomer is responsible for the in vivo chemoprotective properties of equol [30].

Additionally, from pilot data, serum $5 \alpha$-DHT levels significantly decreased by 10 to $15 \%$ in men (50 to 60 years of age) and 20 to $26 \%$ in postmenopausal women (60 to 65 years of age) when an equol oral dose of $3 \mathrm{mg}$ per day was administered (without side effects), suggesting that equol effectively binds and/or alters $5 \alpha$-DHT levels. This pilot data is supported by a recent study showing isoflavone supplementation that increased the production of serum equol in equol-producers resulted in a decline in serum $5 \alpha$-DHT levels in men by approximately $18 \%$ versus before supplementation values [31].

\section{Conclusions}

In summary, our in vitro studies reveal equol binds specifically $5 \alpha$-DHT and prevents increases in PSA from LNCap cells, while the in vivo studies demonstrate that equol decreases rat prostate size, decreases serum $5 \alpha-$ DHT levels and androgen hormone action, while not altering other circulating sex steroids or LH levels. Taken together these data suggest a potential use of equol as a therapeutic agent for men's prostate health. For example, benign prostate hyperplasia (BPH or prostate enlargement) that is manifested by nocturia (need to urinate frequently during the sleep-cycle), frequency of urination during the day or night, decreased voided urine volume, sensory urgency to urinate, inability to start and stop a urine stream, etc., where equol may mediate androgen hormone action of $5 \alpha$-DHT and/or androgen steroid receptor inactivation is influenced by binding ER $\beta$ in a positive manner.

List of abbreviations used

(5a-DHT): 5a- dihydrotestosterone; (AR): androgen receptor; (BPH): benign prostate hyperplasia; (PSA): prostate specific antigen; (LNCap): lymph node metastatic lesion of human prostatic adenocarcinoma; (DMSO): dimethyl 
sulfoxide; (SAM): selective androgen modulator; (ERB): estrogen receptor beta; (LH): luteinizing hormone; (ELISA): enzyme-linked immunosorbent assay.

\section{Acknowledgements}

This work was supported, in part, by a grant from the United States Department of Agriculture (USDA 2004-01811 to EDL). We thank Tim Aucoin for his participation in the binding experiments and Frank Zeigler for assistance with the LNCap cell culture experiment.

\section{Author details}

${ }^{1}$ Stoelting Co., Wood Dale, IL 60191, USA. ${ }^{2}$ The Department of Physiology and Developmental Biology and the Neuroscience Center, Brigham Young University, Provo, Utah 84602, USA. ${ }^{3}$ MRDDRC Imaging Core, Department of Neurobiology, Children's Hospital Boston and Harvard Medical School, Boston, MA 02115, USA.

\section{Authors' contributions}

TDL designed and performed initial binding studies, analyzed data sets and authored portions of this paper. CB analyzed data sets and authored portions of this paper. LB conducted and performed the blood steroid/ hormone assays in all the studies and performed portions of the in vivo animal studies, analyzed data sets and authored portions of this paper. ANH analyzed data sets and authored portions of this paper. EDL designed and performed the in vitro binding assays, LNCap studies and in vivo animal studies, analyzed data sets, authored the paper and obtained funding. All authors read and approved the final manuscript.

\section{Authors' information}

Trent D. Lund, PhD, is president of Stoelting Co., Wood Dale, IL 60191, USA Crystal Blake, PhD, is a research associate in Physiology and Developmental Biology at Brigham Young University (BYU), Provo, Utah 84602, USA. Lihong $\mathrm{Bu}, \mathrm{PhD}$, is MRDDRC Imaging Core manager and instructor, Department of Neurobiology, Children's Hospital Boston and Harvard Medical School, Boston, MA 02115, USA. Amy N Hamaker, is an undergraduate student majoring in Neuroscience at Brigham Young University, Provo, Utah 84602, USA. Edwin D. Lephart, is professor of Physiology and Developmental Biology and The Neuroscience Center at BYU, Provo, Utah, 84602, USA.

\section{Competing interests}

The authors declare that they have no competing interests.

Received: 3 December 2010 Accepted: 13 January 2011 Published: 13 January 2011

\section{References}

1. Manach C, Williamson G, Morand C, Scalbert A, Rémésy C: Bioavailability and bioefficacy of polyphenols in humans. I. Review of 97 bioavailability studies. Am J Clin Nutr 2005, 81(Suppl):230S-242S.

2. Jamison JR: Clinical Guide To Nutrition and Dietary Supplements in Disease Amsterdam, Netherland, Churchhill Livingstone/Elsevier; 2003.

3. Adlercreutz H: Phyto-oestrogens and cancer. Lancet Oncol 2002, 3:364-373.

4. Setchell KD, Brown NM, Lydeking-Olsen E: The clinical importance of the metabolite equol - a clue to the effectiveness of soy and its isoflavones. J Nutr 2002, 132:3577-3584

5. Setchell KD, Clerici C, Lephart ED, Cole SJ, Heenan C, Castellani D, Wolfe BE, Nechemias-Zimmer L, Brown NM, Lund TD, Handa RJ, Heubi JE: S-equol, a potent ligand for estrogen receptor beta, is the exclusive enantiomeric form of the soy isoflavone metabolite produced by human intestinal bacterial flora. Am J Clin Nutr 2005, 81:1072-1079.

6. Hounsome N, Hounsome B, Tomos D, Edward-Jones G: Changes in Antioxidant Compounds in White Cabbage During Winter Storage. Postharvest Biol Tech 2009, 52:173-179.

7. Lund TD, Munson DJ, Haldy ME, Setchell KDR, Lephart ED, Handa RJ: Equol is a novel anti-androgen that inhibits prostate growth and hormone feedback. Biol Reprod 2004, 70:1188-1195.

8. Yang Q, Fung KM, Day WV, Kropp BP, Lin HK: Androgen receptor signaling is required for androgen-sensitive human prostate cancer cell proliferation and survival. Cancer Cell International 2005, 5:8.

9. Lee C, Sutkowski DM, Sensibar JA, Zelner D, Kim I, Amsel I, Shaw N, Prins GS, Kozlowski JM: Regulation of proliferation and production of prostate-specific antigen in androgen-sensitive prostate cancer cells. Endocrinology 1995, 136:796-803.

10. Ozasa K, Nakao M, Watanabe Y, Hayashi K, Miki T, Mikami K, Mori M, Sakauchi F, Washio M, Ito Y, Suzuki K, Kubo T, Wakai K, Tamakoshi A: JACC Study Group: Association of serum phytoestrogen concentration and dietary habits in a sample set of the JACC Study. J Epidemiol 2005, 15(Suppl 2):S196-202.

11. Hoikkala A, Mustonen E, Saastamoinen I, Jokela T, Taponen J, Saloniemi H, Wähälä K: High levels of equol in organic skimmed Finnish cow milk. Mol Nutr Food Res 2007, 51:782-786.

12. Lundh TJO, Pettersson HI, Martinsson KA: Comparative levels of free and conjugated plant estrogens in blood plasma of sheep and cattle fed ostrogenic silage. J Agric Food Chem 1990, 38:1530-1534.

13. Common $\mathrm{RH}$, Ainsworth $\mathrm{L}$ : Identification of equol in the urine of the domestic fowl. Biochim Biophys Acta 1961, 53:403-404.

14. Kuhn G, Hennig U, Kalbe C, Rehfeldt C, Ren MQ, Moors S, Degen GH: Growth performance, carcass characteristics and bioavailability of isoflavones in pigs fed soy bean based diets. Arch Anim Nutr 2004, 58:265-276.

15. Lund TD, Munson DJ, Adlercreutz H, Handa RJ, Lephart ED: Androgen receptor expression in the rat prostate is down-regulated by dietary phytoestrogens. Reprod Biol Endocrinol 2004, 2:5.

16. Pike J, Holmes D, Kamalati T, Davies D, Tolhurst R, Mazhar D, Fishpool S, alJehani R, Waxman J, Zelent A, Lemoine NR, Ali S, Buluwela L: Silencing of androgen-regulated genes using a fusion of AR with the PLZF transcriptional repressor. Oncogene 2004, 23:7561-7570.

17. Legg RL, Tolman JR, Lovinger CT, Lephart ED, Setchell KD, Christensen MJ: Diets high in selenium and isoflavones decrease androgen-regulated gene expression in healthy rat dorsolateral prostate. Reprod Biol Endocrinol 2008, 6:57.

18. Pendleton JM, Tan WW, Anai S, Chang M, Hou W, Shiverick KT, Rosser CJ: Phase II trial of isoflavone in prostate-specific antigen recurrent prostate cancer after previous local therapy. BMC Cancer 2008, 8:132.

19. Hedlund TE, Maroni PD, Ferucci PG, Dayton R, Barnes S, Jones K, Moore R, Ogden LG, Wähälä K, Sackett HM, Gray KJ: Long-term dietary habits affect soy isoflavone metabolism and accumulation in prostatic fluid in caucasian men. J Nutr 2005, 135:1400-1406.

20. Rannikko A, Petas A, Rannikko S, Adlercreutz H: Plasma and prostate phytoestrogen concentrations in prostate cancer patients after oral phytoestogen supplementation. Prostate 2006, 66:82-87.

21. Gardner CD, Oelrich B, Liu JP, Feldman D, Franke AA, Brooks JD: Prostatic soy isoflavone concentrations exceed serum levels after dietary supplementation. Prostate 2009, 69:719-726.

22. Ellem SJ, Risbriger GP: The dual, opposing role of estrogens in the prostate. Ann NY Acad Sci 2009, 1155:174-186, Steroid Enzymes \& Cancer.

23. Lephart ED, Porter JP, Hedges DW, Lund TD, Setchell KD: Phytoestrogens: implications in neurovascular research. Curr Neurovasc Res 2004, 1:455-464.

24. Nomura M, Akama KT, Alves SE, Korach KS, Gustafsson JA, Pfaff DW, Ogawa S: Differential distribution of estrogen receptor (ER)-alpha and ER-beta in the midbrain raphe nuclei and periaqueductal gray in male mouse: Predominant role of ER-beta in midbrain serotonergic systems. Neuroscience 2005, 130:445-456

25. Halbreich U, Kahn LS: Selective oestrogen receptor modulators-current and future brain and behavior applications. Expert Opin Pharmacother 2001, 1:1385-1398.

26. Thornton MJ, Taylor AH, Mulligan K, Al-Azzawi F, Lyon CC, O'Driscoll J Messenger AG: The distribution of estrogen receptor beta is distinct to that of estrogen receptor alpha and the androgen receptor in human skin and the pilosebaceous unit. J Investig Dermatol Symp Proc 2003, 8:100-103.

27. Ashcroft GS, Mills SJ, Lei K, Gibbons L, Jeong MJ, Taniguchi M, Burow M, Horan MA, Wahl SM, Nakayama T: Estrogen modulates cutaneous wound healing by downregulating macrophage migration inhibitory factor. J Clin Invest 2003, 111:1309-1318.

28. Vij U, Kumar A: Phyto-oestrogens and prostatic growth. Natl Med J India 2004, 17:22-26

29. Akaza H, Miyanaga N, Takashima N, Naito S, Hirao Y, Tsukamoto T, Fujioka T, Mori M, Kim WJ, Song JM, Pantuck AJ: Comparisons of percent equol producers between prostate cancer patients and controls: casecontrolled studies of isoflavones in Japanese, Korean and American residents. Jpn J Clin Oncol 2004, 34:86-89. 
30. Magee PJ, Raschke M, Steiner C, Duffin JG, Pool-Zobel BL, Jokela T,

Wahala K, Rowland IR: Equol: a comparison of the effects of the racemic compound with that of the purified S-enantiomer on the growth, invasion, and DNA integrity of breast and prostate cells in vitro. Nutr Cancer 2006, 54:232-242.

31. Tanaka M, Fujimoto K, Chihara Y, Torimoto K, Yoneda T, Tanaka N, Hirayama A, Miyanaga N, Akaza H, Hirao Y: Isoflavone supplements stimulated the production of serum equol and decreased the serum dihydrotestosterone levels in healthy male volunteers. Prostate Cancer Prostatic Dis 2009, 12:247-252.

doi:10.1186/1477-7827-9-4

Cite this article as: Lund et al: Equol an isoflavonoid: potential for improved prostate health, in vitro and in vivo evidence. Reproductive Biology and Endocrinology 2011 9:4.

Submit your next manuscript to BioMed Central and take full advantage of:

- Convenient online submission

- Thorough peer review

- No space constraints or color figure charges

- Immediate publication on acceptance

- Inclusion in PubMed, CAS, Scopus and Google Scholar

- Research which is freely available for redistribution

Submit your manuscript at www.biomedcentral.com/submit 